\title{
Canopy cover as the key factor for occurrence and species richness of subtropical stream green algae (Chlorophyta)
}

\author{
Cleto Kaveski Peres ${ }^{\mathrm{a}, *}$, Aurélio Fajar Tonetto ${ }^{\mathrm{b}}$, Michel Varajão Garey ${ }^{\mathrm{a}}$, \\ Ciro Cesar Zanini Branco ${ }^{\text {b }}$ \\ a Federal University of Latin American Integration (UNILA), Latin American Institute of Life and Nature Sciences, Foz do Iguaçu, Paraná, Brazil \\ b São Paulo State University (UNESP), Laboratory of Aquatic Biology, Assis, São Paulo, Brazil
}

\section{A R T I C L E I N F O}

\section{Article history:}

Received 1 March 2016

Received in revised form 1 November 2016

Accepted 8 November 2016

Available online 9 November 2016

\section{Keywords:}

Benthic macroalgae

Brazilian streams

Shading

Phyto-ecological region

\begin{abstract}
A B S T R A C T
Understanding how local and regional environmental factors influence species richness remains a key issue in ecology. Green algae (Chlorophyta) are a diverse and widely occurring group, which may be a good model for studying the factors that influence species richness at local and regional scales. Here, we tested the influence of local (water quality and structural complexity) and regional environmental factors (phyto-ecological regions) on the occurrence and species richness of macroscopic green algae (MGA) in subtropical streams. We sampled algae in 105 streams located in the four major phyto-ecological regions of the Brazilian subtropics. We used cross-transect technique in streams to sample algae and environmental variables. To determine the most important variables in species occurrence and richness, we used Hierarchical Partitioning analysis (HP). We found that canopy cover alone explained 34\% of MGA occurrence, regardless of phyto-ecological region. At the sites where MGA occurred, the species richness was determined by both regional and local factors. The species richness was mainly influenced by phytoecological region, which explained $34 \%$ of the variation in species richness, along with canopy cover and $\mathrm{pH}$ which explaining $22 \%$ and $15 \%$ respectively. The highest richness was found in non-forested regions, in transects without canopy cover, and slightly acidic $\mathrm{pH}$. Our results illustrate how the combination of regional and local factors can shape the spatial distribution of species richness and are pivotal to understanding richness patterns at broad spatial scales.
\end{abstract}

(C) 2016 Elsevier B.V. All rights reserved.

\section{Introduction}

Hypotheses to explain species distribution in space usually involve local and regional scales (Shurin et al., 2000). The regional species pool is determined by biogeographic and evolutionary processes, such as speciation, extinction and migration (Ricklefs, 2004; Harrison and Cornell, 2008). Furthermore, these processes are influenced by geomorphological and environmental characteristics (Rahbek and Graves, 2001) and historical variations in climate of each region (Carnaval et al., 2009). Thus, species richness may vary between regions as a result of these factors. At the local scale, species composition is a result of species sorting from the regional species pool (Ricklefs, 2004; Vellend, 2010) influenced mainly by local environmental characteristics (Tuomisto et al., 2014) and biotic factors (Morin, 1999), with species tracking environmental variations.

\footnotetext{
* Corresponding author.

E-mail addresses: cleto.peres@unila.edu.br, cletoperes@gmail.com (C.K. Peres).
}

Environmental gradients have been widely related to photosynthetic organisms in lotic habitats. For instance, nutrient (e.g., conductivity, nitrogen, phosphorus), light availability (e.g., canopy cover, turbidity), temperature, $\mathrm{pH}$, hydraulic conditions (e.g., water velocity and depth), grazing rate, and stable substrate availability (Allan and Castillo, 2007) are the most important factors determining photosynthetic organisms distribution in stream realms. These factors exhibit a wide spatial variation, so their influence is related to spatial scale, ranging from microhabitat to regional scale (Frissell et al., 1986), what reflects in ecological patterns still not completely understood or fairly predictable. Hence, more effort is needed to uncover some neglected points regarding ecological distribution of stream dwellers. For example, determining how local and regional environmental factors influence species richness is a key issue in ecology (Ricklefs, 2004, 2008; Brooker et al., 2009), but this approach remains seldom applied for stream algae.

Green algae (division Chlorophyta) are important primary producers in streams (Stevenson, 1996), commonly having higher richness than other macroalgal groups. Thus, macroscopic green algae (MGA) are an interesting group of organisms to investigate 
factors related to richness variations at both local and regional scales. For example, a recent study (Branco et al., 2014) showed that the influence of spatial (e.g. related to dispersal process) and environmental processes (e.g. niche-based process) on the species composition of stream macroalgae varies among taxonomic groups (Cyanobacteria, Chlorophyta, and Rhodophyta). For instance, the taxonomic composition of green algae is influenced by both environment and space, while cyanobacteria only by environment and Rhodophyta only by space (Branco et al., 2014). Thus, local and regional factors may influence algal groups differently. Specifically for MGA, most studies have been conducted at small spatial scales or with limited number of species (Biggs and Price, 1987; Dodds and Gudder, 1992; Okada and Watanabe, 2002). Most of the ecological information about MGA comes from studies dealing with all groups of stream macroalgae. In these studies, some patterns are usually common, such as low endemism rate in each region (Borges and Necchi, 2006), occurrence in a few streams in a region (Branco et al., 2009), dominance by a few species (Necchi et al., 2000; Borges and Necchi, 2006), and local distribution in a mosaic (Necchi et al., 2000, 2003). Nevertheless, how environmental variables determine these distribution patterns is still poorly known (Branco et al., 2009).

The major capability of green algae to grow in habitats with higher irradiance is well accepted and recognized among specialists (Hill, 1996; and references therein). Indeed, previous studies showed that unshaded environments support higher primary production and abundance of green algae. However, the role of irradiance as a key factor on MGA occurrence and species richness is not clear at either regional or local scale. For example, open stream segments do not ensure the presence or high species richness of MGA (Branco and Necchi, 1996; Necchi et al., 2000) and the landscape could be exhibiting an important contribution (Oliveira et al., 2013). Hence, we expect that equally opened stream segments, but from distinct phyto-ecological regions, can exhibit different species richness. This logic led us to assess the species richness and occurrence of MGA regarding environmental factors at local and regional scales in order to check how environmental variables are determining the distribution pattern of MGA.

Herein, we tested the influence of local (water quality and stream structural complexity) and regional factors (phytoecological regions) on the occurrence and species richness of MGA in subtropical streams. We first assessed the occurrence (presence in stream segment) of MGA among all studied streams, regardless of species identity, abundance or species number. After that, we analyzed which factors are determining the MGA species richness in the streams. For this, we sampled MGA in four phyto-ecological regions that encompass very different climatic conditions and vegetation structure (mainly related to light availability). Thus, we predict that MGA species richness will be higher in phyto-ecological regions dominated by herbaceous vegetation (steppe) due to higher light incidence in the whole stream determined by a lower canopy cover. This condition could possibly increase the number of species in the regional pool because MGA have higher photosynthetic capability in places with high light availability (Wetzel, 2001). Furthermore, at local scale (e.g., within stream), other factors could regulate the MGA species richness and, hence, we predict that such factors (e.g., water quality, water flow, stable substrate, and canopy cover) could be influencing the species occurrence and richness of MGA in streams. As a final point, these factors are really important for algal distribution (Stevenson, 1996), and to the best of our knowledge, this is the first study evaluating the relationship of regional and local factors in determining geographical patterns in MGA species richness.

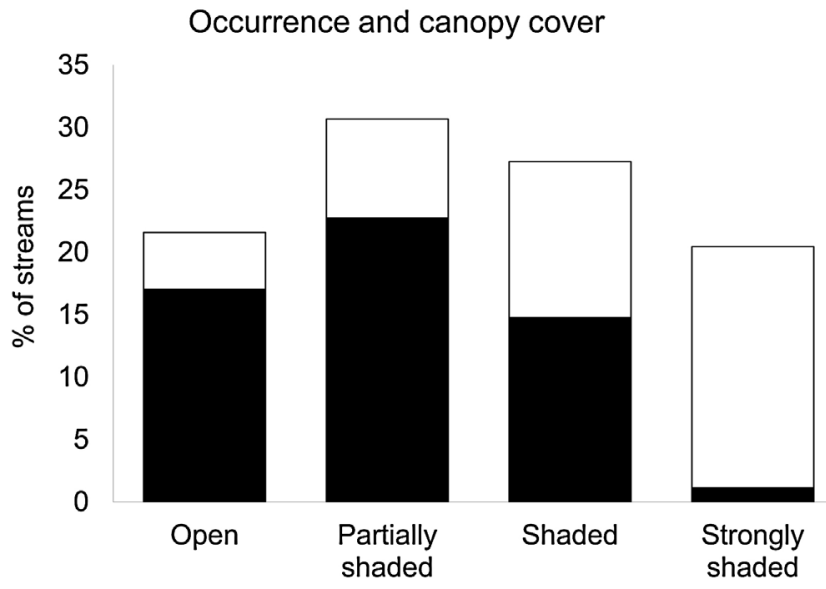

Fig. 1. Percentage of stream transects sampled in each canopy cover class (total bars) and percentage of streams with green algae species occurrence in each canopy cover class (black bars).

\section{Material and methods}

\subsection{Study region}

The sampled area comprises the Brazilian subtropical region

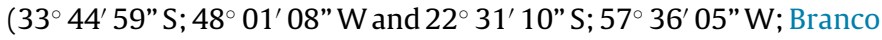
et al., 2014; see their Fig. 1), and is included in the states of Paraná, Santa Catarina and Rio Grande do Sul, located in southern Brazil. The region belongs to humid subtropical zone of oceanic climate, without a defined dry season (Alvares et al., 2013). The Brazilian subtropical area is dominated basically by four phyto-ecological regions (IBGE, 1992) arranged in a mosaic: Seasonal Forest (SF); Mixed Ombrophilous Forest (MOF); Dense Ombrophilous Forest (DOF), and Steppe (ST). These formations were formed and shaped by fire during the quaternary climate changes (Behling and Pillar, 2007). Climatic conditions determine these four phyto-ecological regions (IBGE, 1992). DOF has stable climate defined by high and regular rainfall throughout the year, while in SF, MOF and ST the precipitation is sparsely distributed along the year. Regarding temperature, ST exhibit the highest annual amplitude (winter with frost) and DOF exhibit the lowest temperature variation, while $\mathrm{SF}$ and MOF exhibit an intermediate variation. MOF cover higher altitude areas (more than $700 \mathrm{~m}$ a.s.l.) than SF.

We sampled 105 streams in 10 protected areas distributed in four vegetation formations of southern Brazil (Table 1). The region and stream segments are the same used by Branco et al. (2014) see their Fig. 1). The sampled streams were all inside protected areas to avoid the effect of anthropogenic disturbances.

\subsection{Sampling}

We sampled 105 stream segments (selected by convenience) in the dry periods between 2007 and 2008. The segments were sampled once. To sample the algae, we used $10-\mathrm{m}$ transects, which were further divided into $101-\mathrm{m}$ cross-sections (Sheath and Burkholder, 1985; Necchi et al., 1995, 2000). In each stream transect we analyzed all streambed looking for macroscopic green algae (presence/absence of species). In order to standardize the sampling procedure all transects were sampled for at least $30 \mathrm{~min}$ by the same collectors (CKP, CCZB and AFT). When benthic green algae occurred they were scraped off the substrate in loco using small knives or spatulas. After we have checked all specimens present in the stream segment, we transferred manually small parts of them into plastic flasks containing $4 \%$ formaldehyde. Thereafter, 
Table 1

Protected Areas along phyto-ecological regions (SF = Seasonal Forest; MOF= Mixed Ombrophilous Forest; DOF= Dense Ombrophilous Forest and; ST =Steppe).

\begin{tabular}{|c|c|c|c|c|c|}
\hline Phyto-ecological region & Protected area & Sampled streams & Streams with MGA & Open canopy streams & Location in map \\
\hline \multirow{3}{*}{ MOF } & Irati National Forest, Paraná State & 11 & 1 & 0 & A \\
\hline & Araucárias State Park, Santa Catarina State & 11 & 5 & 0 & $\mathrm{E}$ \\
\hline & Caracol State Park, Rio Grande do Sul State & 10 & 6 & 0 & I \\
\hline \multirow{2}{*}{ DOF } & Saint-Hilaire/Lange National Park, Paraná State & 14 & 2 & 0 & $\mathrm{D}$ \\
\hline & Serra do Itajaí National Park, Santa Catarina State & 10 & 3 & 1 & $\mathrm{~F}$ \\
\hline \multirow{3}{*}{ SF } & Iguaçu National Park, Paraná State & 10 & 3 & 0 & $\mathrm{C}$ \\
\hline & Fritz Plaumann State Park, Santa Catarina State & 9 & 4 & 1 & $\mathrm{H}$ \\
\hline & Turvo State Park, Rio Grande do Sul State & 10 & 8 & 2 & G \\
\hline \multirow[b]{2}{*}{ ST } & Vila Velha State Park, Paraná State & 10 & 8 & 6 & B \\
\hline & Aparados da Serra National Park, Rio Grande do Sul State & 10 & 8 & 9 & $\mathrm{~J}$ \\
\hline
\end{tabular}

a In accordance with Fig. 1 of Branco et al. (2014).

we took these samples to laboratory for taxonomic identification under microscopy (Leica DM 1000) by using specialized literature.

We classified each stream according to a phyto-ecological region (following IBGE, 1992). Environmental variables were measured on each transect (Table 2). Turbidity, conductivity, and $\mathrm{pH}$, were measured at the midpoint of the stream segment using a water analyser with water quality checker Horiba U-10 (a portable electronic device with probes). The percentage of stable substrate was visually estimated (following Gordon et al., 1992). Stable substrates were those larger than $25 \mathrm{~mm}$ (e.g., pebbles, boulder, and solid rock). Canopy cover was estimated in the field into four classes, following DeNicola et al. (1992): open (A), partially shaded (B), shaded (C), and heavily shaded (D). Average water flow and depth of the transect were obtained by averaging the values measured in each section. Water flow was measured using mechanical flowmeter (General Oceanics 2030R) positioned just below the surface for $20 \mathrm{~s}$. Water depth was measured with a vertically positioned ruler. Total dissolved inorganic nitrogen and orthophosphate were measured from a frozen water sample using a spectrophotometer (Spectroquant Nova 60).

\subsection{Data analysis}

We tested for spatial autocorrelation in macroalgal richness using Moran's I correlograms with ten distance classes (Legendre and Legendre, 2012). Moran's I measures the spatial autocorrelation calculated as the product of deviations from the mean (Legendre and Legendre, 2012). Spatial autocorrelation in a given variable can affect the results of linear models, increasing the probability type 1 error (Diniz-Filho et al., 2003). A high positive spatial autocorrelation in the first distance classes for richness means that closer areas have similar richness (Diniz-Filho et al., 2003). Likewise, a high positive autocorrelation in the first distance classes for abundance may suggest that biotic or abiotic variables that determine abundance are spatially structured and should be considered in the analysis, or point to dispersal limitation (Peres et al., 2010). We found a weak positive autocorrelation in macroalgae richness

\section{Table 2}

Independent quantitative variables used in the study with range, mean and standard deviation (SD) $(\mathrm{N}=105)$.

\begin{tabular}{lll}
\hline Variables & Range & Mean +SD \\
\hline Specific conductance (Cond) & $1-63 \mu \mathrm{S} / \mathrm{cm}$ & $27+15$ \\
$\mathrm{pH}(\mathrm{pH})$ & $4.6-7.3$ & $6.2+0.7$ \\
Turbidity (Turb) & $0-86 \mathrm{NTU}$ & $10+13$ \\
Average current velocity (Veloc) & $5-233 \mathrm{~cm} / \mathrm{s}$ & $53+39$ \\
Average depth (Depth) & $3-42 \mathrm{~cm}$ & $16+9$ \\
Orthophosphate (PO4) & $0.01-0.46 \mathrm{mg} / \mathrm{L}$ & $0.09+0.06$ \\
Total Nitrogen (N) & $0.1-4.6 \mathrm{mg} / \mathrm{L}$ & $0.7+0.8$ \\
Stable substrate (Ssub) & $0-100 \%$ & $68+30$ \\
\hline
\end{tabular}

Note: Canopy cover (Canopy) and Phyto-ecological region (Phyto) were registred as categoric variables. only for the first distance class (Fig. S1). However, we found no spatial autocorrelation in the residuals of multiple regression analysis (Fig. S2). This suggest a low Type I error (Peres et al., 2010). Analyses were performed with a SAM software (Rangel et al., 2010).

Independent quantitative variables were standardized to zero mean unit standard deviation prior to analysis. Multicollinearity was assessed using the Variation Inflation Factor (VIF) in the $R$ ( $R$ Core Team, 2012) package car (Fox and Weisberg, 2011). VIF > 3 indicates high multicollinearity, but the VIF of all variables was below that value.

We used all sampling points $(n=105)$ to test the influence of local environmental variables and regional factors on the occurrence (presence or absence in stream segments) of MGA. However, we only included sampling points with at least one species $(n=48)$ to test the influence of environmental variables (local and regional) on the species richness. To test the influence of environmental variables (independent variables) on the occurrence and richness (dependent variables) we used a Hierarchical Partitioning analysis (HP; Chevan and Sutherland, 1991). The HP separates independent variables of a multiple regression model (local or regional) that better explain species occurrence and the distribution of MGA richness. The HP determines the independent effects of predictor variables on the dependent variable (Chevan and Sutherland, 1991). Thus, the independent explanatory power ("I") of each environmental variable on the dependent variable (occurrence and species richness) represents the independent contribution of an environmental variable to the variance explained by the model (Mac Nally, 2002). A second parameter "J" measures the interaction between each environmental variable and the others (Mac Nally, 2002). The results of HP are expressed as Z-score for each independent variable. The Z-score is obtained by conducting 1000 randomizations to generate $95 \%$ confidence intervals. Values of $Z$ greater than 1.65 were considered significant (Mac Nally, 2002).

\section{Results}

We identified 32 species of macroscopic green algae from 11 families (Table S1). The most speciose family was Zygnemataceae with 10 species, followed by Chaetophoraceae with six, and Microsporaceae and Oedogoniaceae with three species each. Only Basicladia emedii Peres \& Branco is an endemic species, restricted to Seasonal Forest.

Approximately half $(n=48)$ of the sampled stream segments had MGA. Species occurrence was higher in transects with higher light intensity. Canopy cover alone explained $34 \%$ of the total variance (Table 3; Fig. 1). Neither other local environmental variable nor vegetation formations explained significantly species occurrence.

Conversely, both local and regional variables influenced species richness. Species richness (mean $=2.2$, standard deviation +1.6 , range $=1-8$, only in stream segments with MGA) was mainly influenced by phyto-ecological region, which explained $34 \%$ of the 
Table 3

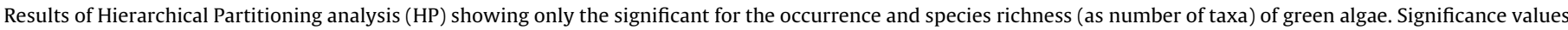

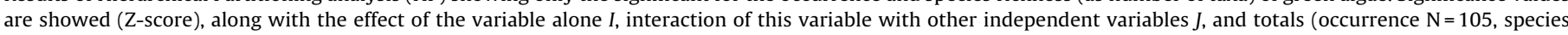
richness $\mathrm{N}=48$ ).

\begin{tabular}{|c|c|c|c|c|c|}
\hline \multirow[t]{2}{*}{ Dependent variables } & \multirow[t]{2}{*}{ Significant independent variables } & \multirow[t]{2}{*}{ Z-score } & \multicolumn{3}{|c|}{ Hierarchical Partitioning } \\
\hline & & & $\mathrm{I}$ & $\mathrm{J}$ & Total \\
\hline Species occurrence & Canopy cover & 11.47 & 0.1751 & 0.1694 & 0.3445 \\
\hline Species & Phyto-ecological region & 2.55 & 0.1851 & 0.1583 & 0.3434 \\
\hline rich- & Canopy cover & 3.08 & 0.0794 & 0.1396 & 0.2190 \\
\hline ness & $\mathrm{pH}$ & 2.82 & 0.0491 & 0.0966 & 0.1457 \\
\hline
\end{tabular}

variation in species richness, along with canopy cover explaining $22 \%$, and $\mathrm{pH}$ which predicted $15 \%$ of the variation (Table 3 ). The most speciose phyto-ecological region was Steppe (Fig. 2A), while the other three (SF, MOF and DOF) exhibited lower and similar values among them. The highest number of exclusive species (i.e., those species found exclusively in one phyto-ecological region) were found in the steppe (Fig. S3). The relative number of MGA species (i.e., total species number per sampling point, including all studied streams, even those without MGA) was low in rain forests ( 0.21 species per point in DOF and 0.38 in MOF), intermediate in seasonal forest (0.52), and high in steppe (0.80). The greatest species richness was found in stream segments with high light incidence (Fig. 2B). Another key variable was $\mathrm{pH}$ and the highest richness (more than three species per sampling segment) occurred in stream segments with pH ranging from 5.2 to 6.5 (Fig. 3).

\section{Discussion}

Our results showed that both local and regional factors influence the distribution of green algae in subtropical streams. However, light incidence stood out as the most important local variable influencing both species occurrence and richness. These results concur with previous studies showing that green algae have a higher photosynthetic efficiency in places with lower canopy cover (Hill, 1996; Necchi, 2004). Thus, the green algae occurrence increases due to the high energy input (Okada and Watanabe, 2002).

Green algae physiological features can explain partly the preference to stream segments with lower canopy cover and consequently more light incidence. This algal group contain a peculiar pigment represented mainly by chlorophyll $a, b$ and carotenoids (Lee, 2008). For instance, carotenoids protect the photosynthetic apparatus against high light intensities and, hence, photoinhibition is low or absent in green algae from well-lit streams (Hill, 1996; Necchi, 2004). Furthermore, differently from any other algal group, green algae exhibit high amounts of chlorophyll $b$ that

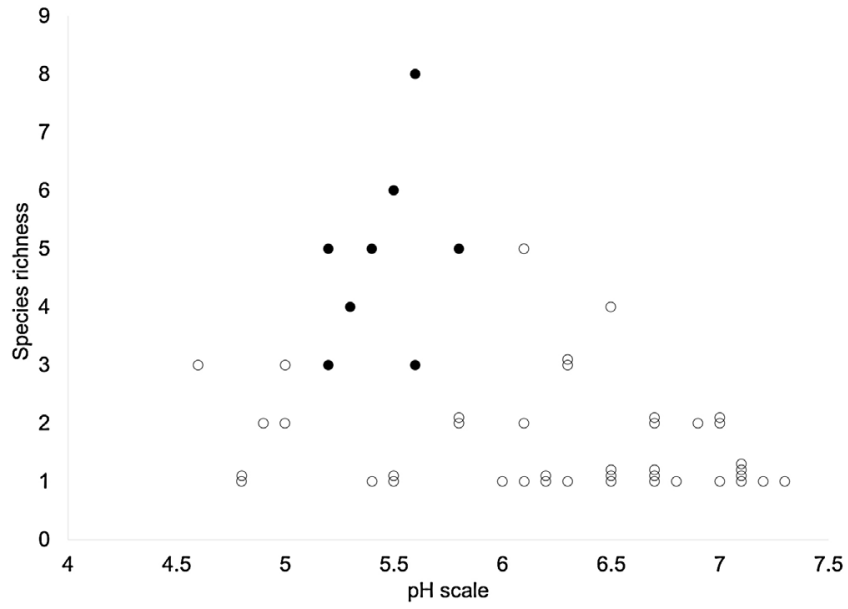

Fig. 3. Species richness of macroscopic green algae in relation to stream $\mathrm{pH}$. Filled circles represent streams without shading from canopy in Steppe regions, and with pH between 5.2 and $5.8(\mathrm{~N}=48)$.

capture other portions of the PAR spectrum (blue and red), enhancing the light absorption (Wetzel, 2001; Necchi, 2004). Thus, the transfer light energy mediated by carotenoids and chlorophyll $b$ to chlorophyll $a$ could explain the higher presence of MGA in opencanopy streams.

Canopy cover has been related not only to the seasonal variation in richness of green algae (Sheath and Burkholder, 1985), but also its local abundance (e.g., Sheath et al., 1996; Tonetto et al., 2012) and species distribution (e.g., Everitt and Burkholder, 1991; Peres et al., 2009). Other studies regarding tropical and subtropical stream macroalgae assessment have not directly addressed the relationship between stream green algae and light incidence (e.g., Necchi et al., 1995; Branco and Necchi, 1996; Krupek et al., 2007; Branco et al., 2009). However, by looking carefully at their data it is

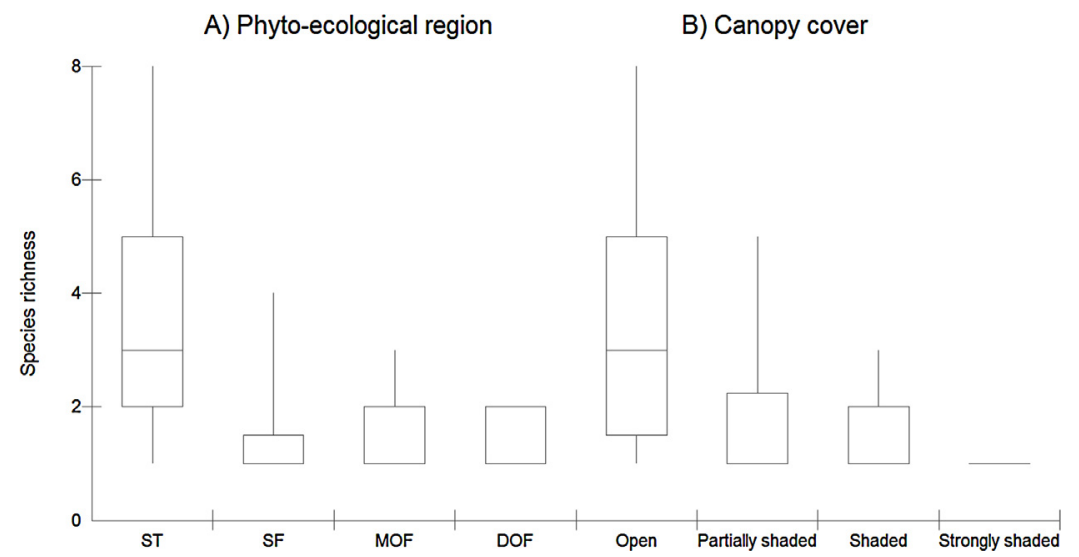

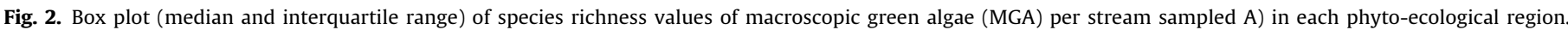

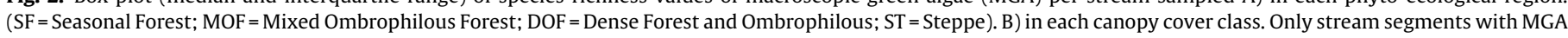
occurrence were considered $(\mathrm{N}=48)$. 
possible to notice a trend of green algae occurrence in stream segments with high light availability. Hence, our study is the first one that directly links the influence of canopy cover on the occurrence and richness of green algae at a regional spatial scale.

Our study was carried out in both forested and non-forested regions. However, most species occurred in the Steppe, despite the predominance of streams in forested regions in our data set. Our results suggests that light incidence is key not only at local scales (i.e., transect), but also at regional scales, where stream segments in regions with herbaceous plants have higher species richness of green algae. Stream segments with higher local richness occurred in regions with also high richness. The influence of regional factors on green algae richness can be explained by the "species pool hypothesis", in which local richness patterns vary as a result of large scale historical factors (Harrison and Cornell 2008; Zobel et al., 2011; Cornell and Harrison, 2014). According to this hypothesis, variation in species richness is explained by changes in extinction, colonization and speciation rates of each phyto-ecological region (Taylor et al., 1990; Schamp et al., 2002). For stream macroalgae in general, endemism is low (Borges and Necchi, 2006) so within a region the main richness increase occurs by colonization of species from other regions. Thus, the species pool of phyto-ecological region will influence the species richness in each stream segment.

Our work showed that phyto-ecological regions with more stable climate (with minimal seasonal variation in weather patterns), as dense ombrophilous forest, have a lower relative species richness of MGA than regions whose seasonal changes are more evident, as steppe. Studies conducted in other countries also showed similar results. For example, a study comprising 1000 stream segments in North America (Sheath and Cole, 1992) suggested that MGA richness among biomes was relatively similar. However, when we re-analyzed their data weighting the species richness by the number of sampling points, the highest species richness was in Chaparral ( 0.46 species per transect), while the lowest was found in Tropical Rain Forest (0.09 species per transect). Therefore, their data showed the same trend of our study. In both cases, streams from forested formations in areas with stable and warm climate have lower algae richness. Interestingly, a greater MGA diversity has been found in open vegetations, like Chaparral and Steppe, than tropical or temperate forests, even though the former are harsh environment for many plants and animals.

The $\mathrm{pH}$ along with canopy cover was a key local variable in determining MGA species richness patterns. There was a narrow variation in $\mathrm{pH}$ in the sampled stream segments, from neutral to slightly acidic, since we only sampled natural areas. However, the effect of this variable on the species richness was hump-shaped, with the greatest species richness in $\mathrm{pH}$ ranging between 5.2 and 6.5. The availability of inorganic carbon (essential for photosynthesis) in aquatic environments is usually regulated by $\mathrm{pH}$ (Allan and Castillo, 2007). Thus, different $\mathrm{pH}$ ranges determine the prevalence of various forms of carbon $\left(\mathrm{CO}_{2}, \mathrm{HCO}_{3}{ }^{-}\right.$, and $\left.\mathrm{CO}_{3}{ }^{2-}\right)$ that can be favorable to different photosynthetic organism groups (Maberly and Spence, 1983). The study by Sheath et al. (1989) found a negative correlation between Chlorophyta diversity and $\mathrm{pH}$, arguing that many species of green algae are not able to use $\mathrm{HCO}_{3}{ }^{-}$as inorganic carbon source. The $\mathrm{pH}$ range (tending to slightly acid) where we found the greatest species richness corresponds to high $\mathrm{CO}_{2}$ availability (Allan and Castillo, 2007), being probably the optimum for many MGA species. Filamentous green algae (especially Zygnemataceae) can dominate aquatic ecosystems affected by acidification (Planas, 1996). Thus, the hump-shaped relationship between richness and $\mathrm{pH}$ reinforces the importance of local environmental factors on algal distribution. Then, most of the MGA in the study area seems to be adapted to the slightly acidic $\mathrm{pH}$.

Our study showed the importance of both regional (i.e., phytoecological region) and local factors (i.e., canopy cover and $\mathrm{pH}$ ) in determining geographical patterns in green algae species richness. Previous studies have demonstrated that the relationship between local and regional factors are an important mechanism in determining the diversity patterns of other taxonomic groups in freshwater habitats (Heino, 2001; Passy, 2009; Lombardo et al., 2013). Both ecological and evolutionary processes affect the distribution of biodiversity (e.g., Harrison and Cornell, 2008), a claim that is supported by many empirical studies (e.g., Buckley and Jetz, 2007). Our results showed that phyto-ecological region, where the streams are inserted (i.e, regional factors), explained great part of the MGA richness variation among the streams (34\% of total variation. See Table 3). Hence, after the influence of regional factors the local environmental factors begin to exert an essential influence on species richness variation of green algae in streams (mainly canopy cover and $\mathrm{pH}$ that explained $22 \%$ and $15 \%$ of the total variation, respectively. See Table 3).

In summary, we suggest that canopy cover is the main variable influencing the occurrence of MGA, regardless of phyto-ecological region. Furthermore, light availability and water $\mathrm{pH}$ seemed to be the key environmental filters influencing species richness. Thus, the greatest species richness were found in non-forest formations, in transects without shading from canopy, and slightly acidic $\mathrm{pH}$. Taken together, our results show how local and regional factors can be integrated to understanding species richness patterns at large spatial scales.

\section{Acknowledgments}

The authors thank IMEA/PRPPG UNILA for financial support, FAPESP (Proc. 2007/52608-1) for financial support of the project "Macroalgas de riachos do Sul do Brasil", CNPq for a doctoral scholarship to CKP (Proc. 141754/2007-9) and a research grant to CCZB (Proc. 302354/2008-5), and ICMBio and the conservation units that were mentioned for granting permission to collect specimens and providing logistical support during our field work. The authors are grateful for the suggestions of Lilian Sayuri Ouchi de Melo and anonymous referees.

\section{Appendix A. Supplementary data}

Supplementary data associated with this article can be found, in the online version, at http://dx.doi.org/10.1016/j.aquabot.2016.11. 004.

\section{References}

Allan, J.D., Castillo, M.M., 2007. Stream Ecology: Structure and Function of Running Waters, 2nd ed. Springer, Netherlands.

Alvares, C.A., Stape, J.L., Sentelhas, P.C., Gonçalves, J.L.M., Sparovek, G., 2013. Köppen's climate classification map for Brazil. Meteorol. Z. 22 (6), 711-728.

Behling, H., Pillar, V.D., 2007. Late Quaternary vegetation, biodiversity and fire dynamics on the southern Brazilian highland and their implication for conservation and management of modern Araucaria forest and grassland ecosystems. Philos. Trans. R. Soc. B 362, 243-251.

Biggs, B.J.F., Price, G.M.A., 1987. A survey of filamentous algal proliferation in New Zealand rivers. New Zeal. J. Mar. Fresh. Res. 21, 175-191.

Borges, F.R., Necchi Jr., O., 2006. Patterns of spatial distribution in macroalgal communities from tropical lotic ecosystems. Rev. Bras. Bot. 29 (4), 669-680.

Branco, C.C.Z., Necchi Jr., O., 1996. Distribution of stream macroalgae in the eastern Atlantic Rainforest of São Paulo State, southeastern Brazil. Algol. Stud. 333 $139-150$.

Branco, C.C.Z., Krupek, R.A., Peres, C.K., 2009. Ecological distribution of stream macroalgal communities from mid-western region of Paraná State, Southern Brazil: importance of local scale variation. Braz. Arch. Biol Technol. 52 (2), 379-386.

Branco, C.C.Z., Bispo, P.C., Peres, C.K., Tonetto, A.F., Branco, L.H.Z., 2014. The roles of environmental conditions and spatial factors in controlling stream macroalgal communities. Hydrobiologia 732, 123-132.

Brooker, R.W., Callaway, R.M., Cavieres, L.A., Kikvidze, Z., Lortie, C.J., Michalet, R., Pugnaire, F.I., Valiente-Banuet, A., Whitham, T.G., 2009. Don't dissintegration: a comment on Ricklefs' disintegrating communities. Am. Nat. 174, 919-927. 
Buckley, L.B., Jetz, W., 2007. Environmental and historical constraints on global patterns of amphibian richness. Proc. R. Soc. Lond. B Biol. 274, 1167-1173.

Carnaval, A.C., Hickerson, M.J., Haddad, C.F.B., Rodrigues, M.T., Moritz, C., 2009. Stability predicts genetic diversity in the Brazilian atlantic forest hotspot. Science 323, 785-789.

Chevan, A., Sutherland, M., 1991. Hierarchical partitioning. Am. Stat. 45, 90-96.

Cornell, H.V., Harrison, S.P., 2014. What are species pools and when are they important? Annu. Rev. Ecol. Evol. Syst. 45, 45-67.

DeNicola, D.M., Hogland, K.D., Roemer, S.C., 1992. Influence of canopy cover on spectral irradiance and periphyton assemblages in a prairie stream. J. N. Am. Benthol. Soc. 11, 391-404.

Diniz-Filho, J.A.F., Bini, L.M., Hawkins, B.A., 2003. Spatial autocorrelation and red herrings in geographical ecology. Global Ecol. Biogeogr. 12, 53-64.

Dodds, W.K., Gudder, D.A., 1992. The ecology of Cladophora. J. Phycol. 28, 415-427.

Everitt, D.T., Burkholder, J.M., 1991. Seasonal dynamics of macrophyte communities from a stream flowing over granite flatrock in North Carolina, USA. Hydrobiologia 222 (3), 159-172.

Fox, J., Weisberg, S., 2011. An R Companion to Applied Regression, 2nd ed. Thousand Oaks, Sage.

Frissell, C.A., Liss, W.J., Warren, C.E., Hurley, M.D., 1986. A hierarchical framework for stream habitat classification viewing streams in a watershed context. Environ. Manage. 10 (2), 199-214.

Gordon, N.D., McMahon, T.A., Finlayson, B.L., 1992. Stream Hydrology: an Introduction for Ecologists. John Wiley \& Sons, Chichester.

Harrison, S., Cornell, H., 2008. Toward a better understanding of the regional causes of local community richness. Ecol. Lett. 11, 969-979.

Heino, J., 2001. Regional gradient analysis of freshwater biota: do similar biogeographic patterns exist among multiple taxonomic groups? J. Biogeogr $28,69-76$

Hill, W.R., 1996. Effects of light. In: Stevenson, R.J., Bothwell, M.L., Lowe, R.L. (Eds.) Algal Ecology: Freshwater Benthic Ecosystem. Academic Press, San Diego, CA, pp. 121-149.

IBGE, 1992. Instituto brasileiro de geografia e estatística. In: Manual Técnico Da Vegetação Brasileira. Série Manuais Técnicos em Geociências, Rio de Janeiro n.

Krupek, R.A., Branco, C.C.Z., Peres, C.K., 2007. Distribuição ecológica das comunidades de macroalgas da bacia de drenagem do Rio das Pedras, região centro-sul do estado do Paraná, Sul do Brasil. Rev. Bras. Bot. 30 (2), 173-182.

Lee, R.E., 2008. Phycology, 4th ed. Cambridge University Press, Cambridge.

Legendre, P., Legendre, L., 2012. Numerical Ecology, 3rd ed. Elsevier Science, Amsterdam.

Lombardo, P., Mjelde, M., Källqvist, T., Brettum, P., 2013. Seasonal and scale-dependent variability in nutrient- and allelopathy-mediated macrophyte-phytoplankton interactions. Knowl. Manage. Aquat. Ecol. 409, 10

Maberly, S.C., Spence, D.H.N., 1983. Photosynthetic inorganic carbon use by freshwater plants. J. Ecol. 71, 705-724.

Mac Nally, R., 2002. Multiple regression and inference in ecology and conservation biology: further comments on identifying important predictor variables. Biodivers. Conserv. 11, 1397-1401.

Morin, P.J., 1999. Community Ecology. Blackwell Malden, Massachusetts

Necchi Jr., O., Branco, C.C.Z., Simões, R.C.G., Branco, L.H.Z., 1995. Distribution of stream macroalgae in northwest region of Sõo Paulo State, Southeastern Brazil. Hydrobiologia 299, 219-230.

Necchi Jr., O., Branco, C.C.Z., Branco, L.H.Z., 2000. Distribution of stream macroalgae in São paulo state, southeastern Brazil. Algol. Stud. 97, 43-57.

Necchi Jr., O., Branco, L.H.Z., Branco, C.C.Z., 2003. Ecological distribution of stream macroalgal communities from a drainage basin in the Serra da Canastra National Park, Minas Gerais, Southeastern Brazil. Braz. J. Biol. 63, 1-12.

Necchi Jr., O., 2004. Light-related photosynthetic characteristics of lotic macroalgae. Hydrobiologia 525, 139-155.

Okada, H., Watanabe, Y., 2002. Effect of physical factors on the distribution of filamentous green algae in the Tama River. Limnology 3, 121-126.
Oliveira, R.C., Tonetto, A.F., Peres, C.K., Branco, C.C.Z., 2013. The landscape influence on the spatial and temporal distribution of stream macroalgal communities of two types of subtropical biomes. Limnética 32, 287-302.

Passy, S.I., 2009. The relationship between local and regional diatom richness is mediated by the local and regional environment. Glob. Ecol. Biogeogr. 8, 383-391.

Peres, C.K., Branco, C.C.Z., Krupek, R.A., 2009. Distribuição ambiental e temporal das comunidades de macroalgas da Serra da Prata, estado do Paraná, Sul do Brasil. Rev. Bras. Bot. 32 (4), 625-633.

Peres-Neto, P.R., Legendre, P., 2010. Estimating and controlling for spatial structure in the study of ecological communities. Global Ecol. Biogeogr. 19, 174-184.

Planas, D., 1996. Acidification effects. In: Stevenson, R.J., Bothwell, M.L., Lowe, R.L (Eds.), Algal Ecology: Freshwater Benthic Ecosystem. Academic Press, San Diego, CA, pp. 497-530.

R Core Team, 2012. R: a Language and Environment for Statistical Computing. R Foundation for Statistical Computing, Vienna, Austria (URL http://www.Rproject.org/).

Rahbek, C., Graves, G.R., 2001. Multiscale assessment of patterns of avian species richness. Proc. Natl. Acad. Sci. Biol. 98, 4534-4539.

Rangel, T.F., Diniz-Filho, J.A.F., Bini, L.M., 2010. SAM: a comprehensive application for spatial analysis in macroecology. Ecography 33, 46-50.

Ricklefs, R.E., 2004. A comprehensive framework for global patterns in biodiversity. Ecol. Lett. 7, 1-15.

Ricklefs, R.E., 2008. Disintegration of the ecological community. Am. Nat. 172 $741-750$.

Schamp, B.S., Laird, R.A., Aarssen, L.W., 2002. Fewer species because of uncommon habitat? Testing the species pool hypothesis for low plant species richness in highly productive habitats. Oikos 97, 145-152.

Sheath, R.G., Burkholder, J., 1985. Characteristics of softwater stream in Rhode Island: II: composition and seasonal dynamics of macroalgae communities. Hydrobiologia 128, 109-118.

Sheath, R.G., Cole, K.M., 1992. Biogeography of stream macroalgae in North America. J. Phycol. 28, 448-460

Sheath, R.G., Hamilton, P.B., Hambrook, J.A., Cole, K.M., 1989. Stream macroalgae of Eastern boreal forest region of North America. Can. J. Bot. 67, 3553-3562.

Sheath, R.G., Vis, M.L., Hambrook, J.A., Cole, K.M., 1996. Tundra stream macroalgae of North America: composition, distribution and physiological adaptations. Hydrobiologia 336, 67-82.

Shurin, J.B., Havel, J.E., Leibold, M.A., Pinel-Alloul, B., 2000. Local and regional zooplankton species richness: a scale-independent test for saturation. Ecology 81, 3062-3073.

Stevenson, R.J., 1996. An introduction to algal ecology in freshwater benthic habitats. In: Stevenson, R.J., Bothwell, M.L., Lowe, R.L. (Eds.), Algal Ecology: Freshwater Benthic Ecosystem. Academic Press, San Diego, CA, pp. 3-30.

Taylor, D.R., Aarssen, L.W., Loehle, C., 1990. On the relationship between r/K selection and environmental carrying capacity: a new habitat templet for plant life history strategies. Oikos 58, 239-250

Tonetto, A.F., Branco, C.C.Z., Peres, C.K., 2012. The effects of irradiance and spectral composition on the establishment of macroalgae in streams in southern Brazil. Ann. Limnol.-Int. J. Lim. 48 (4), 363-370.

Tuomisto, H., Zuquim, G., Cárdenas, G., 2014. Species richness and diversity along edaphic and climatic gradients in Amazonia. Ecography 37, 1034-1046.

Vellend, M., 2010. Conceptual synthesis in community ecology. Q. Rev. Biol. 85, 183-206.

Wetzel, R.G., 2001. Limnology: Lake and River Ecosystems, 3rd ed. Academic Press, San Diego, CA.

Zobel, M., Otto, R., Laanisto, L., Naranjo-Cigala, A., Pärtel, M., Fernández-Palacios, J.M., 2011. The formation of species pools: historical habitat abundance affects current local diversity. Global Ecol. Biogeogr. 20, 251-259. 